Carlos SMANIO'TTO COSTA, Ina ŠUKLJE ERJAVEC, Juliane MATHEY

\title{
Zelene površine - najpomembnejši vir za sonaravnost mest Metoda GreenKeys za razvoj zelenih površin
}

\begin{abstract}
V skladu z načeli trajnostnega razvoja se v vse programe za razvoj mest vključujejo zamisli in ideale o tem, kako mesta razvijati tako, da bodo bolj sonaravna, zlasti z okoljskega in družbenega vidika. Programi temeljijo na iskanju kakovostnejših oblik življenja in rešitev, ki omogočajo tako življenje. Zaradi ekoloških in okoljskih funkcij imajo zelene površine za izboljšanje kakovosti življenja v mestih osrednjo vlogo - zato ker spodbudno vplivajo na zdravje prebivalcev in počutje družbe ter prinašajo gospodarske koristi.

Zelene površine $v$ mestih so zato najpomembnejši vir za oblikovanje sonaravnih mest. V okviru projekta GreenKeys smo razvili metodologijo, ki omogoča kakovostnejšo obravnavo lastnosti zelenih površin. Če nam ne bo uspelo dokazati pomena zelenih površin za življenje v mestih, menimo, da bomo tvegali, da bodo zelene površine ostale na dnu seznama prednostnih nalog v javni politiki in da zanje ne bodo mogli pridobiti več sredstev.
\end{abstract}

$V$ tem članku so kritično predstavljeni rezultati projekta GreenKeys, največ pozornosti pa je posvečene oblikovanju strategije za mestne zelene površine, ki je eden od predlogov tega projekta.

KLUČNE BESEDE: projekt GreenKeys, mestne zelene površine, sonaravnost strategij za mestne zelene površine

\section{Uvod}

Mesta po vsem svetu se hitro spreminjajo, in sicer zaradi močne urbanizacije. Večino primestnih območij vse hitreje zazidavajo; pri tem pa je odstotek zemljišč, na katera je dostop prepovedan, zelo velik. V Evropi spremljajo proces urbanizacije spremenjene gospodarske, demografske in politične razmere (upadanje števila prebivalcev, staranje prebivalstva, deindustrializacija itd.). Te spremembe so hitre ter imajo močan vpliv na naravno in mestno okolje, na zahteve po infrastrukturi in na socialno sestavo mestne družbe.

Načela trajnostnega razvoja od vseh nas zahtevajo, da se zavzemamo za razvoj, ki izpolnjuje zahteve sedanjosti, vendar tako, da ne postavlja ovir prihodnjim
Following the principles of sustainable development all urban development programmes set down ideas and ideals to develop our cities in a more long-lasting way, especially concerning the environment and the social dimension. These programmes result from a process of searching for and then offering a better quality of life. Green space assumes a key role for improving the quality of urban life - not only because of their ecological and environmental functions but also of their relevance for public health, societal well-being and economic benefits they can provide.

Urban green spaces are therefore key resources for sustainable cities. Starting with this principle the GreenKeys Project developed a methodology to approach better green space qualities. Then if we are unable to demonstrate effectively the value that green spaces deliver we risk green spaces remaining on the periphery of public policy priorities and unable to attract more resources.

The article presents and discusses the results and outcomes of the GreenKeys Project. Especially the GreenKeys proposal for supporting the formulation of an Urban Green Space Strategy is widely discussed.

KEY WORDs: GreenKeys, urban green spaces, urban green space strategies sustainability

rodovom pri zadovoljevanju njihovih potreb. Zato ni čudno, da skoraj vsi programi za razvoj mest vključujejo zamisli in ideale o dolgotrajnejšem razvoju mest, zlasti $\mathrm{z}$ okoljskega in družbenega vidika. Programi temeljijo na iskanju kakovostnejših oblik življenja in rešitev, ki omogočajo tako življenje.

Če želimo v mestnih območjih ponuditi kakovostno Življenje, moramo nujno izboljšati kakovost okolja. Mestne zelene površine so osrednji element vseh mest. Vplivajo na mestno krajino, zagotavljajo ekološko raznolikost, spodbudno vplivajo na zdravje meščanov in počutje družbe, prinašajo pomembne gospodarske koristi ter oblikujejo nujne strukturne in funkcionalne prostore, zaradi katerih je življenje v mestih prijetnejše (URGE-Team, 2004). Zelene 
površine so najpomembnejši dejavnik v prizadevanjih za izboljšanje mestnega okolja in kakovosti življenja v mestu. Poleg tega imajo bistveno vlogo pri uresničevanju idealov o sonaravnosti.

Ker je kakovostnih zelenih površin $\mathrm{v}$ mestih pogosto premalo, je treba oblikovati ustrezno strategijo za razvoj in izboljšavo zelenih sistemov mest. Če želimo imeti mestno okolje $z$ manj težavami, boljšo kakovostjo in dobro zapuščino za prihodnje rodove, se moramo spoprijeti $z$ razmerami in to zapuščino ustvariti zdaj. To pa postavlja več vprašanj.

- Kako lahko mesta ustrezno pripravimo, da bodo uspešna v 21. stoletju?

- Kakšne izkušnje bodo prihodnji rodovi dobili od mestnega okolja?

- Kakšno vlogo bodo imele v njem mestne zelene površine?

\section{Opredelitev zelenih površin}

Projekt GreenKeys opredeljuje mestno zeleno površino kot odprt javni prostor na območju mesta, za kateri je značilen visok odstotek rastlinja in neasfaltiranih površin. Neposredna korist mestnih zelenih površin je, da jih prebivalci uporabljajo za aktivno ali pasivno rekreacijo, posredna pa, da spodbudno vplivajo na mestno okolje in zadovoljujejo različne potrebe prebivalcev - s čimer $\mathrm{v}$ mestu omogočajo kakovostno življenje. Zelene površine se pojavljajo v različnih oblikah - kot parki, vrtovi, trgi, pokopališča, vrtički in tudi kot gozdovi in zaščitena naravna območja ter pokrajine. Mestno zelenje je seštevek vseh zelenih površin in sestavlja mestno zeleno tkivo ali mestni zeleni sistem.

Zelene površine so $\mathrm{v}$ mestih dragocene za okolje, družbo in dobro počutje ljudi. Vloge zelenih površin in koristi, ki jih prinašajo, so številne in večplastne. To področje je bolj ali manj poglobljeno raziskalo več avtorjev. Našli so različne dokaze o vlogah in koristnosti zelenih površin. ${ }^{[1]}$ Raztegljivost in večnamembnost pa pomenita, da lahko posamezna zelena površina prinese različne koristi, na različne načine, za različne uporabnike in $\mathrm{z}$ različnimi rezultati. Mestne zelene površine pomembno vplivajo na kakovost sosesk in veliko prispevajo k samobitnosti skupnosti, saj oblikujejo značaj in podobo mesta.

Prepoznavanje pomena zelenih površin in koristi, ki jih prinašajo, pa še ne pomeni, da je razvoj zelenih površin prednostna naloga za politiko. Majhno vlogo v politiki imajo iz različnih razlogov. Po izkušnjah, pridobljenih v projektu GreenKeys, omenjamo te:

- Pri mestnih zelenih površinah moramo upoštevati naravne procese, odnose in interakcije. Ti procesi so počasni, zato lahko šele po dolgem času določimo najvišjo kakovost ter opazimo spremembe in koristi.

- Večina mest in njihovih prebivalcev so zaradi neposrednih koristi zadovoljni že s tem, da zelene površine sploh obstajajo, in se ne sprašujejo o njihovih lastnosti. Zelenih površin zato najpogosteje ne spreminjajo preveč, zanje so značilni zastarela oprema in slab dostop, majhna ekološka vrednost itd. Večjo pozornost bi morali nameniti izboljšanju kakovosti. Čim kakovostnejša je zelena površina, tem več ljudi jo bo cenilo.

- Kadar je zelena površina zanemarjena in nekakovostna (ima nizko ekološko vrednost), je največkrat ne bodo zaprli za javnost - v nasprotju s propadajočimi muzeji in bazeni, ki so jih pristojni prisiljeni zapreti iz zdravstvenih in varnostnih razlogov. Zaprtje takega prostora pa lahko razburi krajane.

- Razvoj mestnih zelenih površin je občutljiv za tangencialne razmere - ker investitorji in nosilci projektov $\mathrm{v}$ zelenih površinah ne vidijo neposredne finančne koristi, se rastoča mesta spopadajo $z$ velikimi pritiski po zazidalnih površinah, manjšajoča se mesta pa $z$ upadanjem dohodka od davkov in $z$ vse več neizrabljenimi površinami.

- Zelene površine veljajo za vir stroškov, zlasti zaradi vzdrževanja. Gospodarske koristi, ki jih lahko prinesejo, pogosto niso prepoznavne in zato tudi niso upoštevane.

\section{Izzivi za razvoj mestnih zelenih površin so vse večji}

Večina mest ima načrt, ki jim omogoča vplivati na količino in kakovost zelenih površin, vendar pa mesta pogosto nimajo primernih celovitih konceptov in

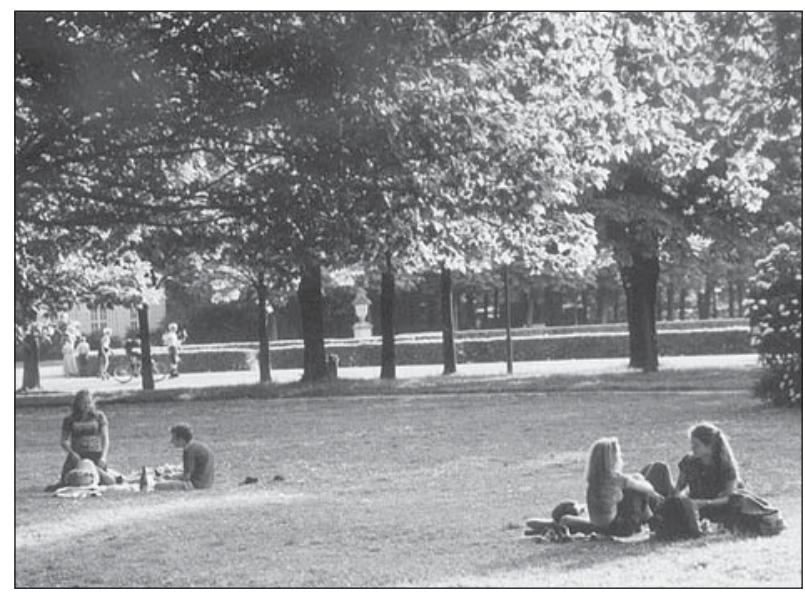

Slika 1: Park Blüherpark v mestu Dresden. Tudi kakovostne zelene površine lahko v skupnosti okrepijo občutek samobitnosti in lastništva (vir: Scherzer, 2006). 
strategij, ki bi razvoj in upravljanje mestnih zelenih površin povezali s splošno politiko urbanističnega razvoja. Ker količina in kakovost zelenih površin po vsej Evropi pogosto nista zadostni, vrednost zelenih površin pa je majhna, je treba oblikovati ustrezne strategije za upravljanje in izboljšanje mestnih zelenih sistemov (URGE-Team, 2004). Zagotovitev razvoja zelenih površin tudi $\mathrm{v}$ obdobju trajnostnega razvoja zahteva trdo delo in zavzetost sodelujočih.

Če nam ne bo uspelo dokazati pomena zelenih površin za življenje v mestih, bomo tvegali, da bodo zelene površine ostale na dnu seznama prednostnih nalog $\mathrm{v}$ javni politiki in da zanje ne bomo mogli pridobiti več sredstev (URGE-Team, 2004). Zato moramo oblikovati in sprejeti take strategije, ki mestne zelene površine bolje umeščajo $\mathrm{v}$ proces odločanja.

Spoprijeti se moramo s sedanjimi in prihodnjimi izzivi, povezanimi s podnebnimi spremembami, $\mathrm{Z}$ varnostjo in s trajnostnim razvojem. Evropsko gospodarstvo mora postati model za trajnostni razvoj $\mathrm{v}$ 21. stoletju, mestne zelene površine pa moramo imeti za dejavnik, ki spodbudno vpliva na krajevno gospodarstvo. Spodbujati moramo dejavnosti $\mathrm{v}$ naravi in dejavnosti, ki zagotavljajo ohranjanje narave, okrasne in rekreacijske površine.

\section{Oblikovanje podnebnih sprememb}

V zadnjih nekaj letih se je znanje o podnebnih spremembah in njihovih posledicah zelo poglobilo in potrdilo prepričanje, da se Zemljino ozračje najverjetneje segreva zaradi človekovih dejavnosti, zlasti zaradi emisij toplogrednih plinov. V iskanju odgovorov na vprašanje, kako naj se mesta prilagodijo negativnim posledicam podnebnih sprememb in "pregrevanju « mestnih območij, nikakor ne smemo spregledati dejstva, da kakovostna sestava zelenih površin ponuja lepo priložnost za preureditev mestnih površin in obrobij, mestom pa omogoča, da se bodo laže spoprijela z izzivi prihodnosti.

Svetovne podnebne spremembe vplivajo na sestavne sektorje mest: na gospodarstvo, družbo, ekologijo, okolje in področja znanosti. Zato je treba oblikovati strategije in metode, s katerimi bomo omilili posledice podnebnih sprememb in se jim prilagodili. Prilagajanje mestnih struktur na posledice podnebnih sprememb je dolgotrajen proces. Če želimo oblikovati trajno strategijo, moramo povezati vse interesne skupine.

\section{Spodbujanje prebivalcev k skrbi za zdravje}

Dostopnost in kakovost mestnih zelenih površin vplivata na telesne dejavnosti prebivalstva. Preživljanje časa na prostem krepi telesno zdravje ter izboljšuje duševni in družbeni razvoj, dobro počutje in kakovost življenja (de Vries, 2001).

Zelene površine zagotavljajo življenjski prostor rastlinam in živalim, hkrati pa so rekreacijska območja in blažijo obremenilni vpliv urbanih dejavnikov - hrupa, smradu, vročine in onesnaženosti ozračja. Preživljanje časa na prostem omogoči človeku, da po bolezni hitreje okreva. Hkrati pa imajo zelene površine v obdobju, za katero so značilni hiter tehnološki in družbeni razvoj ter urbanizacija, funkcijo »tamponske cone«. Blažijo občutek napetosti, ki ga povzročajo okolja z veliko gostoto ljudi, pomanjkanje časa in izguba smeri v življenju. Zaradi zdajšnjega hitrega načina življenja ima vse več ljudi čezmerno težo. S to težavo se lahko spopademo tudi tako, da na prostem zagotovimo več ustreznih prostorov za športne dejavnosti in za skrb za telesno pripravljenost. Parki so idealni kraji za zdravo razgibavanje, vendar jih bodo ljudje s čezmerno težo obiskovali le, če bodo zelo kakovostni (Barber, 2005).

Zelene površine so zato pomemben vir za oblikovanje in načrtovanje zdravega okolja. Kakovost mestnega okolja je v veliki meri odvisna od kakovosti zelenih površin v njem. Če se želimo spoprijeti s težavami, ki so vse večje, morajo biti zelene površine zelo kakovostno oblikovane in opremljene, poleg tega pa morajo biti varne in lahko dostopne.

\section{Projekt GreenKeys - spopadanje $\mathrm{z}$ izzivi zelenih površin kot del skupnega napora}

Cilj projekta GreenKeys je, da se s težavami in $\mathrm{Z}$ izzivi razvoja zelenih površin spoprime vsa družba. Ime projekta razkriva tudi njegov program - Mestno zelenje kot ključ do sonaravnih mest. Koncepti in strategije za trajnostni razvoj mest, ki jih želi oblikovati in uporabiti projekt GreenKeys, temeljijo na mestnih zelenih površinah, ki so primerne $z$ družbenega, okoljskega in gospodarskega vidika.

Osrednji trije cilji projekta so:

1. Zagotovitev spodbud za strukturne spremembe v mestih. Priložnost za izboljšanje zelenih površin ponujajo $\mathrm{z}$ uresničitvijo poskusnih projektov in uporabo pridobljenih izkušenj.

2. Razvoj metodologije $\mathrm{z}$ orodji, s katerimi bodo oblikovali strategijo za mestne zelene površine in izpolnili zahteve, povezane s prihodnjimi potrebami.

3. Z obstoječimi sinergijami spodbuditi prenos znanja po mreži in mednarodno izmenjavo izkušenj. 


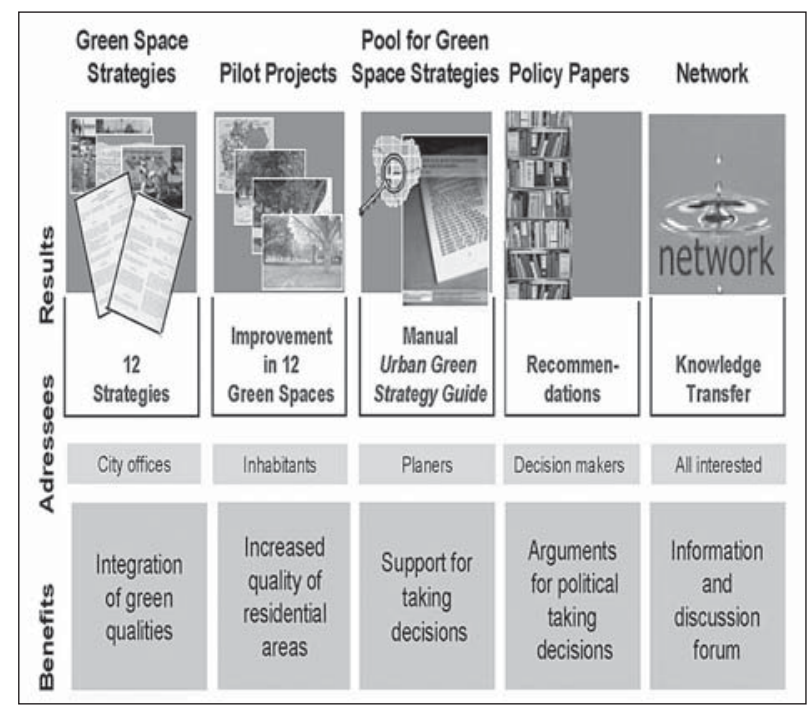

Slika 2: Cilji projekta, zgradba, naslovniki in koristi, ki jim jih je prineslo sodelovanje v projektu GreenKeys (vir: IOER, 2005).

V projektu GreenKeys smo si osrednje cilje prizadevali doseči v petih točkah (povzete so na sliki 2):

1. Predlagan je bil splošni konceptualni okvir za oblikovanje in sprejetje strategije za mestne zelene površine ter razvoj pripomočkov, s katerimi bi olajšali uresničitev te naloge. Sedmo poglavje obravnava postopek oblikovanja strategije za mestne zelene površine in jih ponazarja $\mathrm{z}$ nekaj pridobljenimi spoznanji.

2. Pri uresničevanju poskusnih projektov so udeleženci uporabili nove zamisli in tehnike, s katerimi so oblikovali nove oziroma izboljšali obstoječe zelene površine. Poseben poudarek so namenili dejavnemu sodelovanju skupnosti pri razvoju poskusnega projekta, s čimer so želeli skupnosti ponuditi priložnost za boljšo usposobljenost in krepitev moči.

3. Zbrane izkušnje smo pregledali in zbrali v priročniku, z naslovom GreenKeys @ Your City - A Guide for Urban Green Quality. Priročnik je bil oblikovan, da bi pomagal pri iskanju odgovorov na vprašanja, povezana z zelenimi površinami. Vsebuje znanstveno in tehnično znanje, bil pa naj bi tudi "pripomoček za pogovore«, kanal, ki naj bi izboljšal in okrepil komunikacijo z nasveti ter spodbudil k (drugačnemu) razmišljanju in spoznavanju zapletenih interakcij med potrebami prebivalcev, okoljskimi zahtevami in ponudbo zelenih površin.

4. V projektu GreenKeys smo na podlagi domneve, da bi bilo mestne zelene površine mogoče bolje upravljati, če bi imele podporo državnih teles in Evropske unije ter če bi bile podprte z izsledki analiz, oblikovali priporočila za upravljavce mest, države in Evropsko komisijo, in sicer v obliki poročil. Zdajšnji evropski in nekateri nacionalni dokumenti o urbanistični politiki kažejo, da se je »sonaravnosti mest « vendarle uspelo uvrstiti med téme političnih razprav, čeprav je to le posredno povezano z razvojem zelenih površin. Urbanistična politika, ki bi se izrecno ukvarjala z zelenimi površinami na državni ali evropski ravni, pa za zdaj ne obstaja. O priporočilih projekta GreenKeys smo veliko razpravljali s partnerji in $\mathrm{z}$ udeleženci zaključne konference, ki je bila aprila 2008 v Sofiji (Bolgarija). Priporočila so del priročnika GreenKeys@ Your City - A Guide for Urban Green Quality.

5. Razvoj strategij za mestno zelenje je učni proces, ki ga je treba spodbujati z izmenjavo znanja in s primerjavo izkušenj. Za lažje posredovanje znanja smo oblikovali mrežo. Med njenimi nalogami so bili analiza, posredovanje izkušenj in tehnike, ki so jih domači udeleženci potrebovali za oblikovanje in uporabo stroškovno učinkovitih sonaravnih urbanih strategij.

V okviru projekta GreenKeys smo za boljšo izmenjavo in boljše posredovanje znanja priredili sklepni dogodek, mednarodno konferenco, $\mathbf{z}$ naslovom Urban Green Spaces - a Key for Sustainable Cities (Mestne zelene površine - ključ do sonaravnih mest). Konferenca je potekala v Sofiji, 17. in 18. aprila 2008. Udeležilo se je je približno 170 predstavnikov različnih držav, ki so predstavili delne rezultate projekta GreenKeys in o njih razpravljali, razložili so orodja ter predstavili poskusne projekte in strategije mestnih zelenih površin partnerskih mest. Izkušnje projektov iz vse Evrope so zbrane v konferenčnem zborniku, dostopnem prek povezave http://www.greenkeys-project.net/ en/conference.html

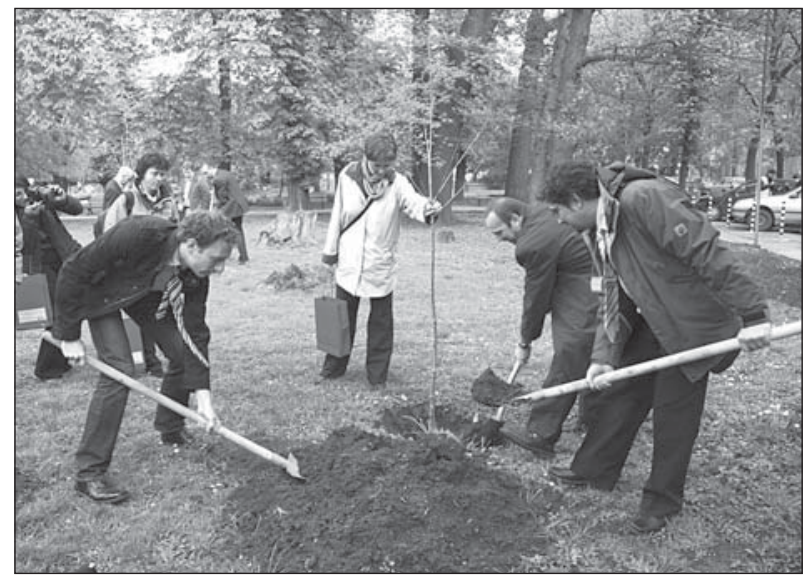

Slika 3: Delegati so se med konferenco lahko udeležili vodenih ogledov po zelenih površinah Sofije. Poleg tega so kot znak zaupanja v prihodnost v parku lahko posadili drevesa. 


\section{Projekt GreenKeys in njegovi partnerji}

Projekt GreenKeys je nastal zato, da je obravnaval vse močnejše zahteve po zagotavljanju zdravih življenjskih razmer v mestnih okoljih. V njem je sodelovalo 20 partnerskih ustanov - dvanajst mest in osem ustanov iz Bolgarije, Nemčije, Grčije, Madžarske, Italije, Poljske in Slovenije. Partnerji smo od maja 2005 do avgusta 2008 delovali kot interdisciplinarna ekipa. Slika 4 prikazuje seznam vseh partnerjev projekta GreenKeys. Imena mest se nanašajo na oddelek ali oddelke, ki so dejavno sodelovali pri projektu. Podroben seznam vseh partnerskih ustanov in udeležencev $\mathrm{z}$ naslovi in s telefonskimi številkami je dostopen na spletni strani projekta.

Projekt GreenKeys delno financira pobuda Evropske unije ITERREG III B na območju CADSES, podpira pa ga ministrstvo za transport, gradbeništvo in urbanizem Zvezne republike Nemčije. Projekt GreenKeys je vodil urad za upravljanje $\mathrm{z}$ mestnimi zelenimi površinami in odpadki pri mestni občini Dresden, na znanstvenem področju pa ga je usklajeval Leibnizov inštitut za ekološki in regionalni razvoj.

V projektu je svojo vlogo našla tudi evropska dimenzija. Mesta partnerji projekta GreenKeys se med seboj tako zelo razlikujejo, da smo lahko z uveljavljenimi dobrimi praksami veliko pridobili. Mesta se razlikujejo po velikosti, lokaciji in funkcijah. V projektu so sodelovale državne prestolnice, na primer Budimpešta in Sofija, glavna mesta regij, med njimi Dresden (Nemčija) in Bydgoszcz (Poljska), ter majhna mesta, kot sta Giulianova (Italija) in Kotel (Bolgarija).

\section{Izzivi za strategijo mestnih zelenih površin}

Kot smo že omenili, je bil eden izmed osrednjih ciljev projekta GreenKeys razviti metodologijo z ustreznimi orodji in $\mathrm{z}$ njo opredeliti strategijo za mestne zelene površine. S širitvijo te metodologije smo želeli mestom po vsej Evropi pomagati, da bolje in uspešnejše obravnavajo ta pomembni vidik mestnega tkiva. Prepričani smo, da bo uresničevanje te strategije pripomoglo k izboljšanju kakovosti življenja $v$ mestih in njihovemu sonaravnemu razvoju.

Zelene površine se v mestu oziroma mestnem tkivu pojavljajo v najrazličnejših oblikah, v najrazličnejši sestavi in v različnih tipih. Uspešna zaščita, oblikovanje in razvoj teh površin so nekateri izmed bistvenih elementov, ki so potrebni za sonaravni razvoj mest. Preučevanje in razvoj zelenih površin pa sta zapleteni nalogi, in sicer zaradi:

- vpliva dolgotrajnih naravnih procesov, ki so del rasti in dozorevanja živih elementov, ter

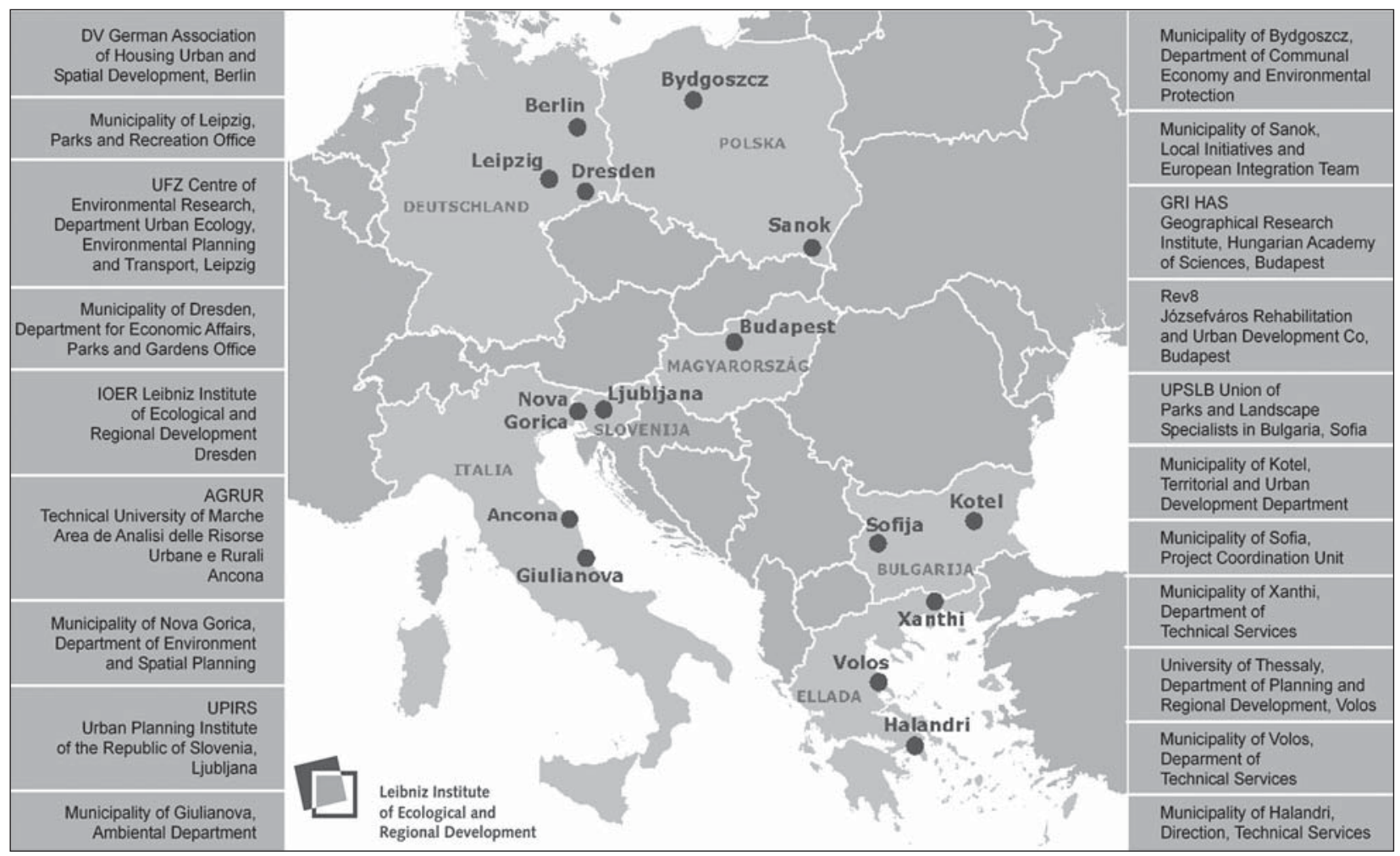

Slika 4: Seznam vseh partnerjev projekta GreenKeys (vir: IOER, 2008). 
- dejstva, da zelene površine simbolizirajo javne vrednote ter pomembno vplivajo na dobro počutje in zdravje prebivalcev.

To, kako javnost sprejema in ceni zelene površine, je odvisno od njihovih lastnosti, kot so razpoložljivost, kakovost in dostopnost.

Trendi, ki jih zdaj opažajo v številnih evropskih mestih, kažejo, da se kakovost obstoječih mestnih zelenih površin na splošno slabša. Brez zadostne politične in finančne podpore državnih in lokalnih oblasti, drugih skladov in zasebnih vlagateljev upravljanje zelenih površin tega procesa ne bo moglo zaustaviti oziroma obrniti. Dejavnosti javnih upravnih teles oziroma organizacij, odgovornih za zavarovanje in razvoj zelenih površin, zahtevajo strateški razvoj ter strateško načrtovanje in upravljanje.

Strategija je pravzaprav politika za doseganje različnih ciljev. Oblikovati bi morala osrednjo metodo, tako, ki je primerna za doseganje ciljev in reševanje posebnih vprašanj. Strategije za zelene površine morajo ustrezati različnim (ekološkim) okoljskim, družbenim in gospodarskim politikam in ciljem sonaravnega razvoja. Poleg tega morajo biti zagovorniki teh strategij v političnem diskurzu procesa odločanja in razporejanja sredstev sposobni braniti svoje cilje in ne dopustiti, da jih spregledajo zaradi drugih ciljev razvoja mesta in načrtovanja.

Namen strategije za zelene površine je zato:

- zavarovati prihodnosti zelenih površin,

- izboljšati kakovosti mestnih območij, zlasti sosesk,

- povečati privlačnost mestnih območij in s tem pritegniti več virov ter

- izboljšati počutje domačinov in turistov.

Torej bi morala biti strategija oblikovana tako, da bi zagotavljala boljšo izrabo potenciala zelenih površin in da bi pomagala spore reševati že vnaprej.

Sodelujoči v projektu GreenKeys smo sprejeli strategijo mestnih zelenih površin, ki temelji na izhodiščih CABE Space (2004): strategija za mestne zelene površine oblikuje skupno vizijo za izboljšane zelene površine, površine, ki bodo zadovoljevale potrebe skupnosti ter zagotavljale referenčno točko za razporeditev virov in načrtovanje dejanj.

Mesta se med seboj razlikujejo, vsako ima svoje prostorske razmere, potenciale, priložnosti, težave in zahteve ter družbene, kulturne in zgodovinske okoliščine. Vsako mesto ima drugačno upravno ureditev, drugačne finančne in človeške vire ter drugačno urbanistično zakonodajo. Iz izkušenj mest partnerjev projekta GreenKeys in vsakodnevnih praks vemo, da ni vedno mogoče, smiselno in uspešno razviti enako strategijo za vsa mesta. Izhodišče za strategijo za razvoj je lahko v drugačnih razmerah povsem drugačno. Zato je upravičeno pričakovanje, da bo moralo vsako mesto poiskati svojo pot za nadaljevanje dela na tem področju.

Po drugi strani pa so nekatere splošne naloge in nekateri koraki, nekatere vsebine/zgradbe strategije v procesu obvezni in nujni za vse, ki želijo oblikovati učinkovito in uporabno strategijo zelenih površin.

Ker se je ekipa projekta GreenKeys zavedala teh skupnih strateških potreb, je sklenila, da v sodelovanju z mesti partnerji razvije tak proces oblikovanja strategije, ki bo dovolj odprt in prilagodljiv, da bo zajel različne razmere, hkrati pa bo omogočil razvoj takšne strategije zelenih površin, ki bo "preprosta in izvedljiva za vse«. Zato smo se pri oblikovanju metodologije strategije za mestne zelene površine in njenem uresničevanju odločili za dvojni pristop. Pri tem smo si pomagali z izkušnjami partnerjev z znanstvenega področja, z analizo literature in s študijami primerov. Oblikovali smo več orodij, s katerimi želimo mestom pomagati začeti strateški proces, analizirati razmere v mestu in oblikovati strategijo mestnih zelenih površin.

Mesta partnerji so ob pomoči teh orodij začela proces oblikovanja svoje strategije za mestne zelene površine. Njihovi predstavniki so znanstvenim partnerjem poročali o težavah in ovirah, s katerimi se srečujejo mesta, ter opisali koristnost orodij, ki jih uporabljajo.

Ekipa projekta GreenKeys je analizirala vse podatke, ki jih je dobila od mest, zakonodajne in urbanistične okvire, znotraj katerih morajo delovati mesta partnerji, ter proces razvoja strategije. Za boljše rezultate je še dodatno razvila uporabljena orodja. To je spodbudilo razvoj zbirke strategij, ki so pomemben del priročnika projekta GreenKeys. S to zbirko smo želeli mestom, ki ne sodelujejo v projektu, pomagati, da prepoznajo svoj potencial zelenih površin in razvijejo svoje strategije mestnih zelenih površin.

Projekt GreenKeys želi z »zbirko strategij《 predstaviti ter uveljaviti novo razmišljanje in nove zamisli, takšne, ki podpirajo izzive razvoja, oblikovanja in uresničevanja strategije zelenih površin. Zamisel temelji na zavedanju, da številna mesta nimajo ne izkušenj ne zakonske podpore za pripravo strategije zelenih površin ter da se zato že od začetka procesa spopadajo z velikimi težavami in ovirami.

$\mathrm{Z}$ analizo izkušenj mest partnerjev projekta GreenKeys in nekaterih drugih primerov, ki smo jih 
spremljali med projektom, smo ugotovili, da se mesta pri svojem vsakdanjem delu srečujejo $\mathrm{z}$ nekaterimi skupnimi težavami ter nenapovedljivimi in nepričakovanimi okoliščinami. Večina teh okoliščin izstopa ter jih teoretična literatura in priročniki ne obravnavajo. Za pomoč $\mathrm{v}$ takih primerih smo $\mathrm{v}$ zbirki strategij zbrali različne praktične rešitve z nekaterimi prav domiselnimi postopki, ki so jih posamezna mesta uporabila za premagovanje težav in ovir pri oblikovanju strategije mestnih zelenih površin. Po izkušnjah projekta GreenKeys so lahko taki primeri dobro izhodišče oziroma navdih za druga mesta.

Med projektom GreenKeys smo ugotovili, da se mesta na začetku oblikovanja strategije najpogosteje srečujejo s temi težavami in ovirami:

- slaba oziroma neobstoječa podpora politike in javnosti,

- oblikovanje strateške skupine,

- pomanjkljiva ali neustrezna prostorska zakonodaja,

- oblikovanje izhodišč (razvojne vizije),

- opredelitev ciljev in splošnih prednostnih nalog.

Večini mest, ki so sodelovala v projektu GreenKeys, je te težave in ovire uspelo premagati, tako da je lahko začela oblikovati svojo strategijo.

Pri analitičnem delu oblikovanja strategije so najpogostejše težave pomanjkanje dobrih, uporabnih po- datkov in finančnih (in človeških) virov, s katerimi bi podprli ta del procesa. Zbrali smo različne analitične metode in razvili nekatera orodja (opisana so v naslednjem poglavju). Z njimi želimo mestom pomagati, da ta del organizirajo kar najučinkovitejše in najuporabnejše.

Posebno pozornost smo namenili vprašanjem analitičnega povzetka, oblikovanju tipologije mestnih zelenih površin in postavljanju lokalnih meril, ki so lahko dober temelj za nadaljnji razvoj strategije, zlasti za pripravo strateških vprašanj, prednostnih nalog in načrta delovanja.

Tehnika projekta GreenKeys ni načrt, ki se ga je treba strogo držati; je predvsem model, ki ponuja proces za oblikovanje strategije mestnih zelenih površin. Med projektom smo oblikovali osnovni okvir, ki se nam zdi nujen in uporaben za vse in $\mathrm{v}$ vseh razmerah oblikovanja strategije za zelene površine. Temelji na izkušnjah partnerjev projekta GreenKeys, ustrezne literature (CABE Space Guide, UK PPG17) in drugih izkušenj mest, ki so bile predstavljene med projektom.

Ne glede na splošne elemente in podrobnosti strategije bodo vedno obstajali trije deli, ki jih bo treba razviti in oblikovati:

- začetek (uvodne dejavnosti),

- analitični del (zbiranje podatkov in presoja) in

- dejavni del (oblikovanje strategije).

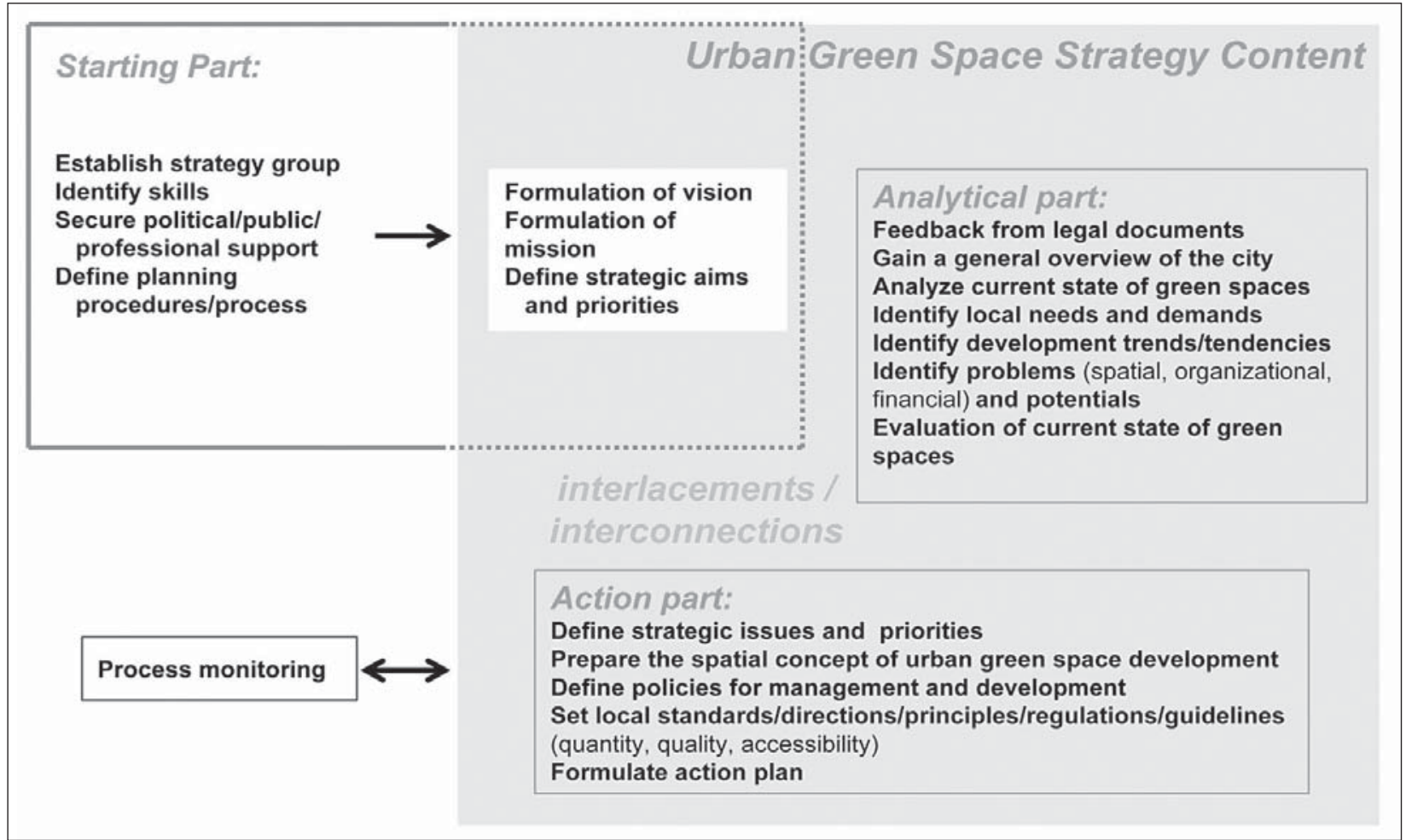

Slika 5: Elementi strategije zelenih površin projekta GreenKeys (vir: UPIRS, 2007). 
Med projektom smo razvili sistem spremljanja oblikovanja strategije. Izkazalo se je, da je koristen in nujen.

Oblikovanje strategije za mestne zelene površine je za večino evropskih mest nekaj novega, zato zahteva intenzivno in prepričljivo pionirsko delo. Oblikovanje strategije za mestne zelene površine je obsežen in precej zahteven proces, ki obravnava sedanje razmere na področju zelenih površin z vidika skupnih vrednot ter potreb družbe in njenih gospodarskih možnosti. Če želimo, da bo strategija uspešna, moramo delo dobro organizirati, hkrati pa poskrbeti tudi za sodelovanje med mestnimi oddelki, interesnimi skupinami in javnostjo. Delo moramo organizirati tako, da ustreza značilnostim posameznega mesta.

Navzkrižno pridobljeni podatki o razvoju metodologije za oblikovanje strategije mestnih zelenih površin kažejo, da morajo pobudo za razvoj mestnih zelenih površin dati predstavniki mesta. Pobudo nato podprejo še regionalna in državna vlada ter Evropska unija.

\section{Dodatna orodja za analizo in boljše delovanje mestnih zelenih površin (sistemov)}

Za tradicionalno metodo ocenjevanja in razvoja zelenih površin je pogosto značilna toga cepitev na sektorske analize. Posamezni oddelki mestne uprave obravnavajo samo svoje interesno področje. Strategije za razvoj mestnih zelenih površin, ki temeljijo na taki sektorski metodi, pogosto ne dosežejo soglasja. Z njimi največkrat dosežejo le količinski cilj (to je oblikovanje dodatnih zelenih površin), medtem ko potreb krajanov, gospodarskih dejavnikov, širših urbanističnih ciljev in celo kakovostnih vidikov zelenih površin (biološka raznolikost in dostopnost) tako rekoč ne upoštevajo. Strategije za mestne zelene površine, oblikovane s tako metodo, zato niso v skladu s krajevnimi razmerami. Ta učinek se še dodatno okrepi, kadar načrtovanje in razvoj zelenih površin izrinejo drugi vidiki urbanističnega razvoja (stanovanjska naselja, infrastruktura ipd.) (URGE-Team, 2004).

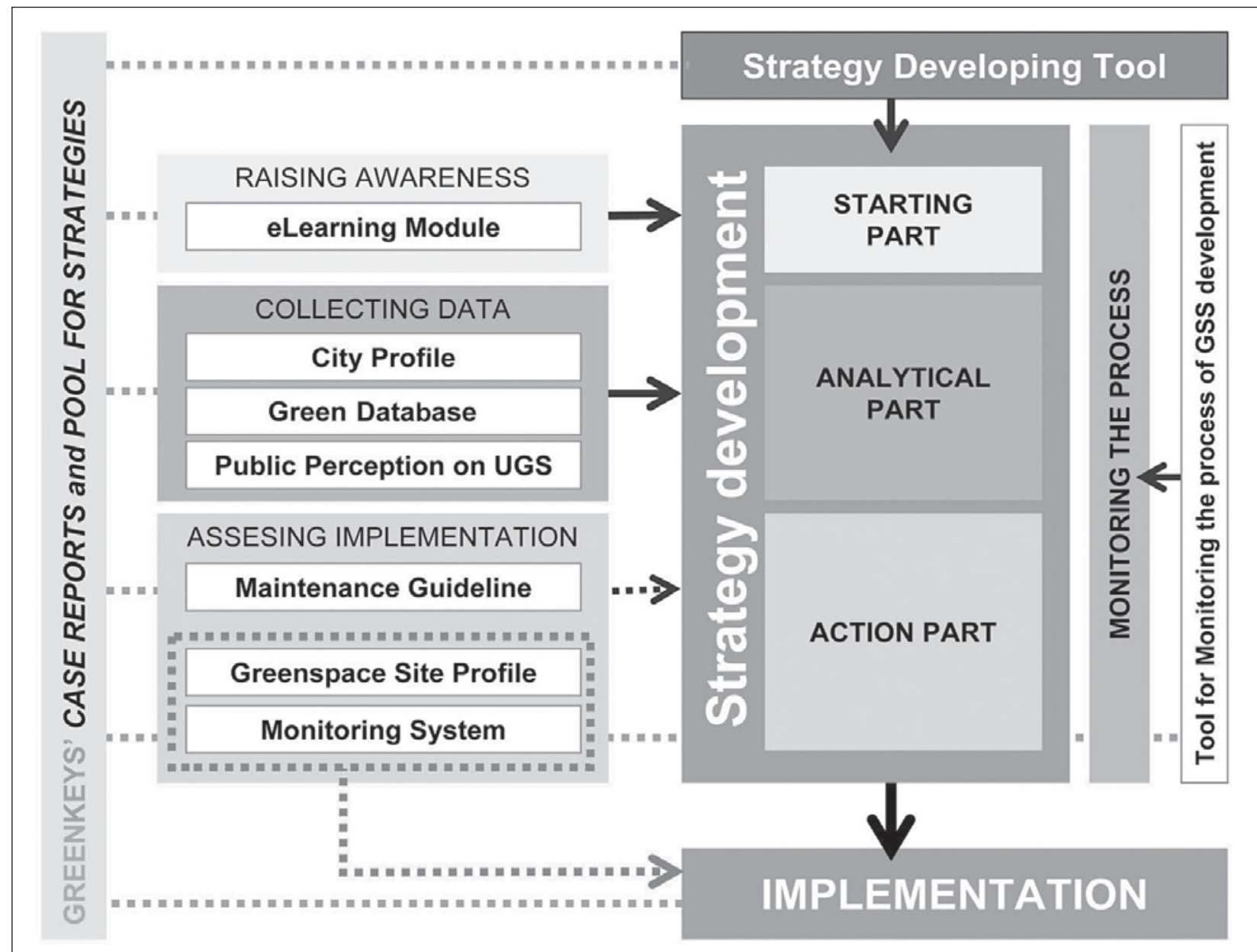

Slika 6: Orodja in njihova vključitev - uporaba orodij projekta GreenKeys pri razvoju mestnih zelenih površin in procesu upravljanja ter prikaz, kako podpirajo oblikovanje strategije mestnih zelenih površin. 
V okviru projekta GreenKeys smo se vprašanja ustvarjanja bolj zdravega pozidanega okolja ob pomoči boljših zelenih površin lotili celovito. Izdelali smo metodologijo za razvoj, oblikovanje in uresničevanje strategije mestnih zelenih površin za vse mesto. V podporo procesu smo razvili več orodij. Podporna orodja so združena v GreenKeys Toolbox, zbirki med sabo usklajenih instrumentov, tehnik in priporočil, ki bodo pripomogli k boljšemu razumevanju mestnih zelenih površin in pomagali pri prihodnjem odločanju o naložbah. Orodja, ki smo jih razvili pri projektu GreenKeys, in spremljevalni dokumenti so na voljo $\mathrm{v}$ priročniku ter dostopni prek povezave www.greenkeys-project.net

Slika 6 je splošni pregled orodij projekta GreenKeys ter njihove uporabe pri razvoju mestnih zelenih površin in v procesu odločanja. GreenKeys Toolbox ponuja priložnost za razvoj in spremljanje razvoja strategije za mestne zelene površine, za spremljanje sprememb v projektih za zelene površine, za pridobivanje podatkov o tem, kako ljudje vidijo gospodarski vpliv mestnih zelenih površin, ter za upravljanje podatkov o profilu mesta in značilnostih zelenih površin. Orodja omogočajo zbiranje in organiziranje primerljivih podatkov o vseh projektih, s tem pa tudi podrobnejšo obdelavo in analizo.

Orodja projekta GreenKeys so:

- eLearning Module (modul za e-učenje). Ta modul je oblikovan za obveščanje o procesih in razpravah, povezanih $\mathrm{z}$ razvojem strategij upravljanja mest. Namenjen je predvsem tistim, ki se srečujejo s tem vprašanjem, niso pa strokovnjaki zanj (politiki, nosilci odločanja, člani mestne uprave itd.), torej tistim, ki želijo več podatkov o pomenu in prednostih mestnih zelenih površin za razvoj mestnega okolja. Modul je oblikovan kot dokument v formatu HTML. Deluje v poglavitnih operativnih sistemih (Windows $\AA$ in Mac $($ ) in $z$ najpogostejšimi brskalniki, zato se lahko uporablja tudi pri delavnicah in tečajih.

- City Profile (profil mesta) je vprašalnik, namenjen zbiranju podatkov o splošni zgradbi in organizaciji mesta glede na njegovo ponudbo zelenih površin. $Z$ vprašalnikom želimo ugotoviti značilnosti fizičnega, ustavnega, institucionalnega in operativnega okolja mesta. Podatki o teh značilnosti so izjemno koristni za razumevanje lokalnega sistema. Še posebej koristna sta zgradba sistema ter način njegovega delovanja za prostorsko načrtovanje in upravljanje mesta. Podatki, zbrani z vprašalnikom City Profil, uporabniku omogočajo samoevalvacijo, ki služi kot temelj za strategijo mestnih zelenih površin in za uspešno izvršitev z njo povezanih zelenih projektov. City Profile in Green Space Site Profile (profil lokacij zelenih površin) zagotavljata podatke za Green Database (zeleno bazo podatkov).

- Strategy Developing Tool (orodje za razvoj strategije) je pripomoček, ki lokalni upravi in upravnim telesom olajša sodelovanje, pri strategiji mestnih zelenih površin ter njeno organizacijo, njen razvoj in njeno uresničevanje. To orodje podpira ter usmerja načrtovanje in vodenje razvoja take strategije s ciljem, da oblikuje vizijo za sonaravno prihodnost mesta. "Strategy Development Took vsebuje "Strategy Development Guide« (vodnik za razvoj strategije), ki zagotavlja delovni okvir (postopek, ki temu sledi, pa mora biti seveda v skladu s krajevnimi razmerami in z zahtevami), in spremljevalno "Content Table« (tabelo vsebin) za hiter pregled.

- Strategy Developing Monitoring Table (tabela za spremljanje razvoja strategije) je orodje, ki pomaga uporabniku spremljati razvojni proces strategije za mestne zelene površine. Osrednji namen tega orodja je preverjanje in spremljanje procesa oblikovanja strategije mestnih zelenih površin ter njenega časovnega in vsebinskega razvoja. Izpolnjena tabela omogoča hiter pregled nad položajem ter je primerna oblika predstavitve politikom in javnosti. Ponuja dobre možnosti za oblikovanje trdne, celovite in trajne strategije za zelene površine.

- Maintenance Guideline (smernice za vzdrževanje) vsebujejo nasvete in podporo, ki evropskim mestom omogočajo oblikovati in uporabiti svojo strategijo, svoje metode in svoja orodja za vzdrževanje mestnih zelenih površin. Smernice opozarjajo na številne ključne dejavnike, ki pripomorejo $\mathrm{k}$ temu, da je vzdrževanje mestnih zelenih površin čim boljše. Zato so v dokumentu našteta tudi številna vprašanja, o katerih morajo razmisliti občine med oblikovanjem strategij za vzdrževanje zelenih površin. Razvrstimo jih lahko na šest ključnih vsebin - vizija, spremljanje, organizacija, usposobljenost, financiranje in sodelovanje.

- Tool for Public Perceptions and Attitudes towards Urban Green Spaces (orodje za ugotavljanje stališč in odnosa javnosti do mestnih zelenih površin) lahko mestne oblasti uporabijo za ugotavljanje mnenj in stališč meščanov o obstoječih in morebitnih zelenih površin $\mathrm{v}$ mestu, tudi $\mathrm{v}$ povezavi $\mathrm{z}$ gospodarskimi vidiki mestnih zelenih površin. Vprašalnik raziskuje odnose do alternativnih rab mestnih zelenih površin, ukvarja pa se tudi $z$ vprašanji njihovega financiranja, vzdrževanja in širitve. Zavedati se je treba, da so stališča meščanov pomembna za mesto, saj so lahko temelj oblikovanja oziroma preoblikovanja politike o mestnih zelenih površinah.

- Green Space Site Profile je vprašalnik, s katerim želimo mestom pomagati pri organizaciji, 


\section{GRTe'NKEYS}

URBAN GREEN AS A KEY FOR SUSTAINABLE CITIES

\begin{tabular}{|l|l|l|l|}
\hline City & Date & \\
\hline Institution & & \multicolumn{2}{|l|}{} \\
\hline
\end{tabular}

\begin{tabular}{|ll|}
\hline I. & Area, land use and population \\
\hline I.I. & $\begin{array}{l}\text { Please indicate the area for development of the } \\
\text { green strategy } \\
\text { Reference year for the above data: }\end{array}$ \\
& $\begin{array}{l}\text { Please specify the kind of boundary you use to determine this area (e.g. city area, } \\
\text { municipality area, administrative border, urban region area, etc.) }\end{array}$ \\
\hline
\end{tabular}

> A map with the borders mentioned in I.I could be very useful

\section{I.3. Land use (built up area, except urban green and open spaces)}

\begin{tabular}{|l|c|c|c|}
\hline $\begin{array}{l}\text { Area types (You can use your own land } \\
\text { use categories instead of the proposed } \\
\text { (e.g. according to a land use plan such as } \\
\text { the "Flächennutzungsplan" or urban } \\
\text { biotope mapping results.) }\end{array}$ & Total area & Proportion & $\begin{array}{l}\text { Proportion of } \\
\text { green + open } \\
\text { spaces inside the } \\
\text { area }\end{array}$ \\
\hline Residential areas & $\mathrm{km}^{2}$ & $\%$ & $\%$ \\
\hline Industrial areas & $\mathrm{km}^{2}$ & $\%$ & $\%$ \\
\hline Commercial areas & $\mathrm{km}^{2}$ & $\%$ & $\%$ \\
\hline Mixed use areas & $\mathrm{km}^{2}$ & $\%$ & $\%$ \\
\hline $\begin{array}{l}\text { Infrastructure (Roads and other transport } \\
\text { routes) }\end{array}$ & $\mathrm{km}^{2}$ & $\%$ & $\%$ \\
\hline Land use (built up area) (total) & $\mathbf{k m}^{2}$ & $\%$ & $\%$ \\
\hline \begin{tabular}{l} 
Other, please specify \\
\multicolumn{2}{|c|}{$\mathrm{km}^{2}$}
\end{tabular} & $\%$ & $\%$ \\
\hline $\begin{array}{l}\text { Are there GIS/digital based maps of the land } \\
\text { uses available? Please describe briefly the contents of } \\
\text { these maps. }\end{array}$ & $\mathrm{km}^{2}$ & \\
\hline Reference year for the data above & & \\
\hline I.4. & & \\
\hline
\end{tabular}

\begin{tabular}{ccc}
\hline$\cdots$ & GreenKeys is part-financed by the European Union Community & Initiative INTERREG III B \\
& www.greenkeys-project.net & $\ddots$ \\
\hline
\end{tabular}

Slika 7: Primeri vprašanj iz profila mesta projekta GreenKeys. 
spremljanju in evalvaciji razvoja novih zelenih površin in izboljšavi obstoječih zelenih površin. $\mathrm{Na}$ podlagi podatkov, pridobljenih $\mathrm{z}$ vprašanji, želimo opisati značilnosti posameznega zelenega projekta in njegovega izvajanja. Vprašalnik olajša evalvacijo obstoječih razmer (značilnosti, prednosti, potrebe, težave itd.) in proces uresničevanja, hkrati pa tudi oblikovanje ocene mogočih izidov.

- Green Database je Microsoftova predloga za podatkovno bazo, ki vključuje vprašanja iz vprašalnikov City Profil in Green Space Site Profil. Green Database omogoča sistematično in učinkovito obdelavo skupine podatkov, in sicer tako, da zagotavlja hitro iskanje in hiter prikaz povezanih podatkov. Baza podatkov omogoča oblikovanje povezanih baz podatkov, in sicer v obliki tabel, makroukazov, postavljanja vprašanj in tiskanih poročil. Omogoča pridobitev podatkov o različnih projektih in posameznem projektu v različnih obdobjih.

- GreenKeys Monitoring System (sistem nadzora GreenKeys) je orodje, ki poskrbi za to, da spre- membe opazimo, omogoča pa tudi oblikovanje novih oziroma nadgradnjo obstoječih mestnih zelenih površin. Z 32 jasnimi in izmerljivimi numeričnimi kazalci zagotavlja preprost in učinkovit nadzor nad izvajanjem projektov. Poleg tega pomaga med izvajanjem projektov zelenih površin spremljati uresničevanje ciljev, ki smo si jih zastavili. Napredek lahko prikažemo, zato lahko hitro ugotovimo morebitna razhajanja.

Orodja City Profile, Maintenance Guideline, Tool for Public Perceptions and Attitudes towards Urban Green Spaces in Green Space Site Profile so na voljo v dveh različicah, in sicer v formatu PDf/Adobe Acrobat, $v$ katerem je mogoče podatke samo vnesti, in $\mathrm{v}$ formatu MS Word, ki ga je mogoče prilagajati $\mathrm{v}$ skladu z željami in s potrebami.

Orodje Strategy Developing Monitoring Table je na voljo v formatu MS Word v dveh oblikah - kot obrazec, v kateri je mogoče samo vnesti podatke, in kot dokument, ki ga je mogoče prilagoditi v skladu z željami in s potrebami.

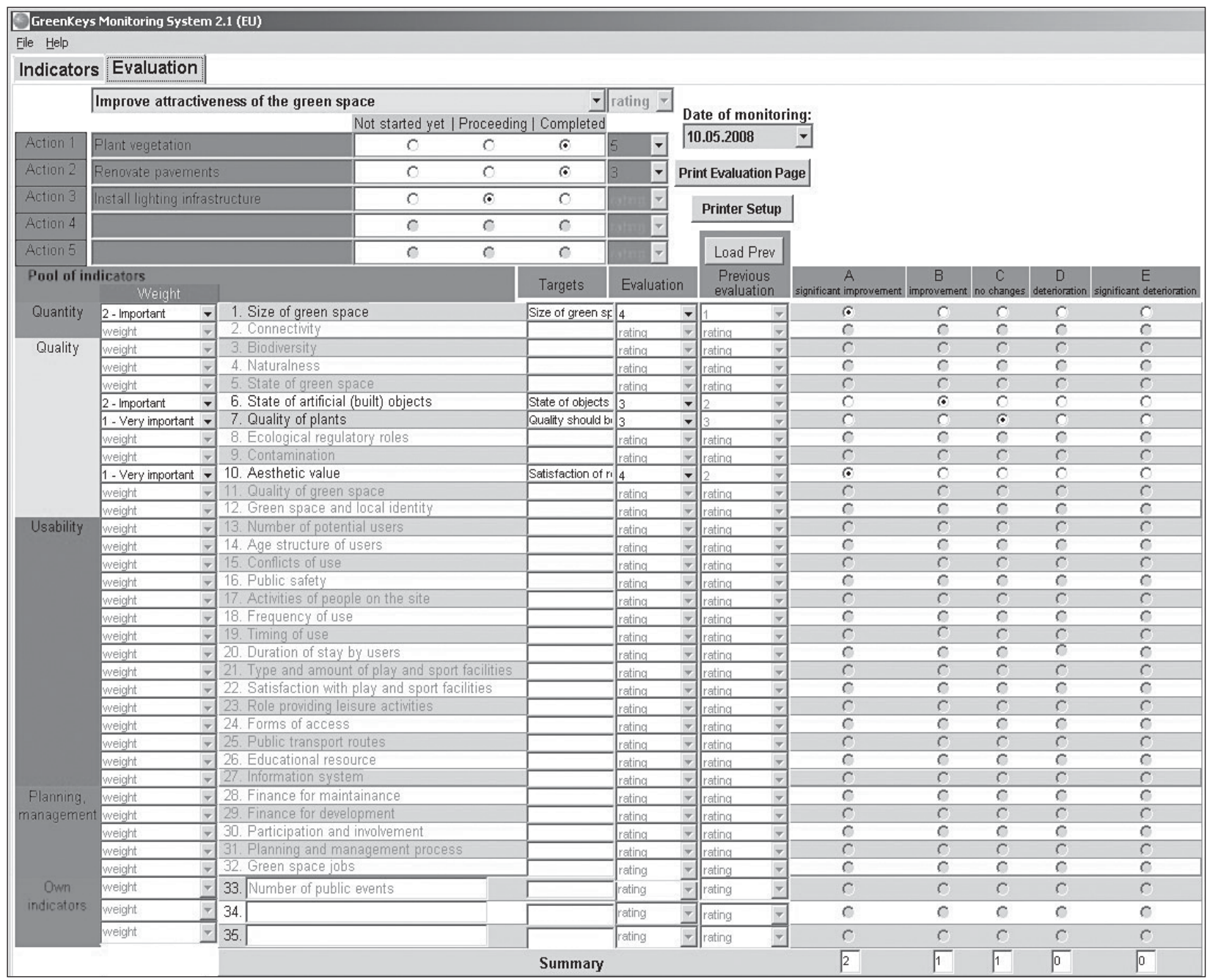

Slika 8: Primer evalvacijske pole sistema nadzora GreenKeys. 


\section{Podpora učnega procesa $\mathrm{V}$ praksi - izvajanje poskusnih projektov}

V skladu s cilji projekta so vsa mesta partnerji uresničila svoje poskusne projekte ${ }^{[2]}$, s katerimi so pridobili koristi prebivalci in okolje določenega območja. Mesta so $\mathrm{v}$ povezavi s krajevnimi interesnimi skupinami ustvarila nove zelene površine oziroma izboljšala obstoječe. Posebno pozornost so namenila družbenim, ekološkim in gospodarskim zahtevam. Namen projekta je bil, da vprašanje razvoja zelenih površin obravnavamo drugače in oblikujemo nove metode.

Primeri poskusnih projektov so:

- novo ovrednotenje stanovanjskih naselij z izboljšanjem zelenih površin (mesti Xanthi in Budimpešta),

- oblikovanje območij za šport in rekreacijo na zelenih površinah (mesta Volos, Giulianova in Sanok),

- preobrazba zapuščenih zemljišč $v$ zelene površine (mesti Leipzig in Nova Gorica),

- prenova zgodovinskih parkov (mesti Dresden in Kotel) in botaničnega vrta (mesto Bydgoszcz) ter izboljšanje odprtih prostorov $\mathrm{z}$ endemičnimi rastlinami (mesto Halandri).

Pri izvajanju teh poskusnih projektov smo želeli še:

- zagotoviti priložnost za rekreativne, športne in razvedrilne dejavnosti,

- izboljšati dostopnost in uporabnost,

- zagotoviti povezavo z izobraževalnimi in/ali kulturnimi dejavnosti, predvsem na področjih arheologije, zgodovine in okolja,

- izboljšati varnost in poskrbeti za varnejšo rabo mestnih zelenih površin,

- izboljšati splošno podobo mesta,

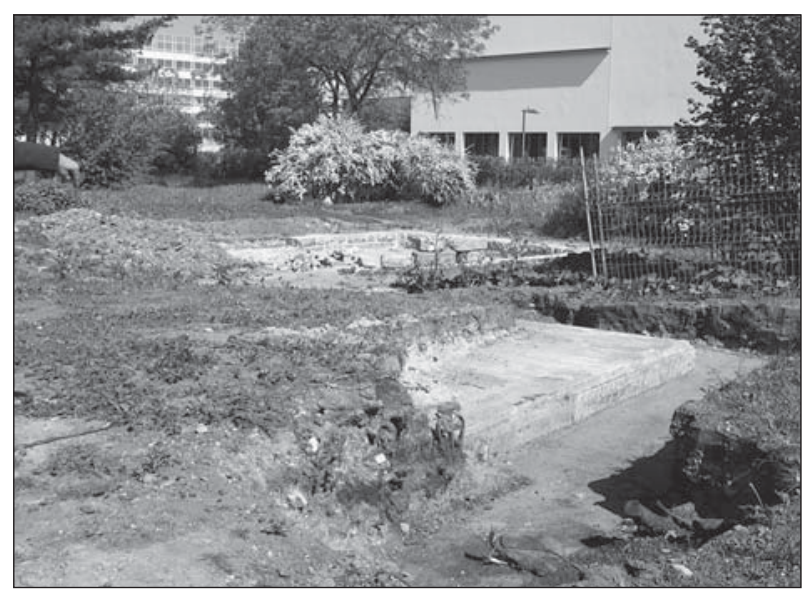

Slika 9: Izkopavanja v mestu Dresden so razkrila zanimive podrobnosti o nekdanji obliki parka (vir: Dresden, 2006).
- ponuditi storitve za skupine uporabnikov s posebnimi potrebami, to je otrokom,

- razviti družbenopolitično dimenzijo - poglobiti in izboljšati sodelovanje javnosti in njeno ozaveščenost, okrepiti družbeno tkivo območja oziroma mesta kot celote ter

- povečati biološko raznolikost.

Pri vprašanjih, povezanih z zelenimi površinami, mora imeti javnost pomembno vlogo, saj so zelene površine in javnost ključni elementi trajnostnega razvoja. V poskusnih projektih smo zato veliko pozornost posvetili prav sodelovanju javnosti.

Sodelovanje javnosti je zapleteno vprašanje. V projektu GreenKeys smo se posvetili:

- razlogom za sodelovanje javnosti in obsegu sodelovanja,

- prepoznavanju udeležencev oziroma gonilne sile med njimi in

- časovnemu usklajevanju sodelovanja (kdaj koga vključiti).

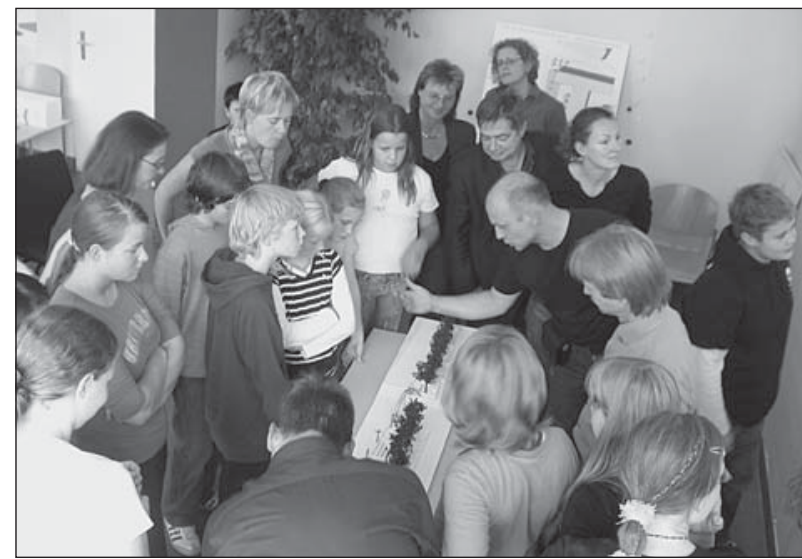

Slika 10: Kresanje zamisli s študenti o kotičku za mladostnike v parku Bürgerpark v Leipzigu (vir: Grünfläschenamt, Leipzig, 2007).

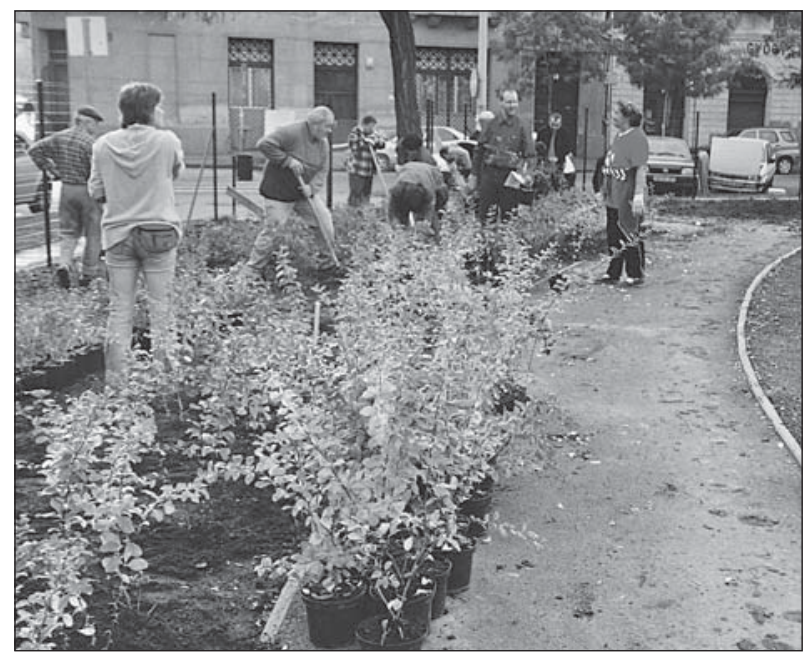

Slika 11: Prebivalci sadijo drevesa v Budimpešti. 

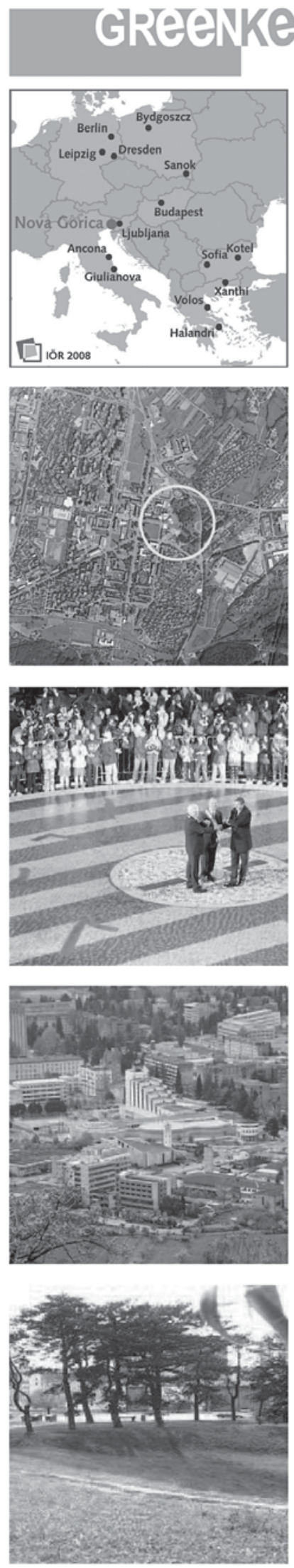

GreenKeys is part-financed by the European Union Community Initiative INTERREG III B www.greenkeys_project.net

$16 / 06 / 2008$

\section{NOVA GORICA, Slovenia}

\begin{tabular}{|l|l|l|l|}
\hline Municipality area & $13 \mathrm{~km}^{2}$ & Population & $20.000(2002)$ \\
\hline GDP per inhabitant & $\begin{array}{l}15170 \quad € / \text { year (for } \\
\text { Slovenia 2006) }\end{array}$ & Trend & decreasing \\
\hline Area of green spaces & all open spaces: $5,43 \mathrm{~km}^{2}$; urban green spaces: $0,43 \mathrm{~km}^{2}$ \\
\hline Area of green spaces per inhabitant & $271,5 \mathrm{~m}^{2} /$ inh. (all open spaces); $21,5 \mathrm{~m}^{2} /$ inh. (urban green spaces) \\
\hline
\end{tabular}

\section{Nova Gorica and its green structure}

Nova Gorica is situated within a flat valley, on the edge of Goriška plain and is surrounded by low hills to the north, east and south.The municipality lies close to the border between Slovenia and Italy, hence Nova Gorica has close ties with the Italian city of Goricia. The maritime climate, with hot summers and mild winters, allows the use of urban green spaces throughout the year.

The city is surrounded by wide green areas which in places penetrate the urban tissue. Within the city there are many smaller green areas: some are already developed as parks whilst others remain untendered and unkempt. Panovec urban forest plays a very important role in the city's urban structure as a recreational and leisure facility.

Nova Gorica was planned with a strong influence from the modernism movement as a 'city in green'. This concept is noticeable in the city structure which is distinguished by wide, parallel and perpendicular streets together with intervening built structures and green spaces. These are not, however, equally distributed within the urban fabric and some residential areas, especially those that are newly built, suffer from a deficiency of urban green spaces.

There is an accelerating trend to give up agricultural land use within the urban area. This results in deterioration into unused accommodation land and building plots for development of new residential areas. As the expansion of the city is limited there are pressures to preserve those spaces which have not yet been built upon.

There are some studies and projects (ecological stability, protection of biotopes and species, vulnerability of recreation areas) that support the development of urban green spaces. To achieve this, minor problems remain such as insufficient finance, political instability, bureaucracy, maintenance, an ineffective green planning system, lack of cooperation within the administration and growing pressures to build on the areas.

Another problem the city is confronted with relates to questions of land ownership following independence. The issue of ownership of most of the major green spaces within the high density residential areas is still proceeding before the competent court. The tendency to privatize public space through this judicial process can lead to a limiting and shrinking of public green spaces. The challenge of the municipality is to prevent the spread of this process and to secure ownership of urban green spaces.

\section{Urban green space strategy}

\section{The challenges and approach to building an urban green space strategy}

There is no legally binding spatial legislation for green space strategy development in Slovenia, so the municipality chose not to accept GSS as an independent document.

A working version of such a document has been created by the city administration while working on the Green Strategy issue. As a consequence of this work we now have a preliminary draft of the Green Space Strategy which provides:

- the vision;

- goals;

- guidelines for modifying appropriate spatial documents and administrative acts (such as the master plan, the town's urban plan, its strategic and implementing section, ordinances on maintenance of public areas, ordinance on the city appearance);

- guidelines on green space typology (type, inventory, quality, deficiencies, policy)

The Strategy foresees:

- the establishment of required registers, such as the green areas register, and the planted species register

- how and when set goals are to be reached;

- the basic coordination amongst task performers; and

- the completion of the basic goal of the draft - presenting the Green Space Strategy to the City Council to gain its approval.

At the present time there is a low level of political and public support for preparing the green space strategy. The first and most important challenge is to raise public awareness and political interest about importance and benefits of a green space strategy for the city. A public information publication about the possibilities and challenges of urban green in the city has been prepared as a first step towards the green space strategy. Once the publication has been presented to the municipal administration to get legal support the development of the strategy will follow.

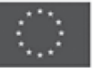

Slika 12: Primer poročila (Nova Gorica). Poročila so na voljo v rubriki City Folder v CD-ROM Tools. 
Sodelovanje ima lahko tudi politični pomen in ta pogosto določi njegove lastnosti. Ideologija/politični pomen opredeljuje obseg sodelovanja, to pa vpliva na izbiro strategije, ki okrepi ideologijo/politični pomen.

Pri načrtovanju in izvajanju poskusnih projektov smo uporabili ta orodja: profil mesta, opis pilotnega projekta, orodje za ugotavljanje stališč in odnosa javnosti, sistem nadzora ter bazo podatkov $\mathrm{z}$ informacijami o vsakem izmed pilotnih projektov.

Ta orodja so nam omogočila podobno tehniko zbiranja in urejanja podatkov o vseh projektih. Podatke smo pozneje podrobneje obdelali. Z zbiranjem in analizo podatkov smo pridobili pomembno znanje, zato smo strategije za mestne zelene površine lahko obogatili z zadovoljivo empirično bazo. Projekt GreenKeys je poleg izvedbe pilotnih projektov dobil tudi dodano vrednost, saj je oblikoval dragocena orodja za splošno rabo "zelenih površin« in »strategije za zelene površine«.

Izvedba poskusnih projektov kljub spodbudam (večjemu proračunu in pomoči pri izmenjavi znanja) ni vedno potekala brez težav. Najpogostejše težave (razvrščene so od najbolj do najmanj pogostih), so bile:

- skromno sodelovanje javnosti pri nekaterih ali vseh fazah projekta oziroma tega sodelovanja sploh ni bilo;

- nesodelovanje med posameznimi ravnmi in oddelki lokalne uprave, odgovornimi za projekt in/ ali vključenimi vanj;

- slabo načrtovanje in slabo upravljanje, ki ga je poslabšalo pomanjkljivo sodelovanje med posameznimi ravnmi in oddelki;

- premalo človeških virov in dodatne, nenačrtovane naloge;

- birokratski in/ali zakonski zapleti in z njimi povezane zamude;

- pomanjkanje politične podpore;

- vandalizem;

- zahteve po spremembah projekta in z njimi povezane zamude;

- pomanjkanje sredstev - vsako mesto partner je za izvedbo poskusnega projekta namenilo dodatna proračunska sredstva. Vendar je ta proračun zahteval sofinanciranje, kar je v nekaterih mestih povzročilo težave.

\section{Kratko poročilo o sodelovanji javnosti}

Oceno sodelovanja je težko oblikovati. »Objektivne« evalvacije ne moremo doseči zaradi različnih kategorij sodelujočih $\mathrm{z}$ različnimi motivi in cilji sode- lovanja. Sodelovanje lahko na splošno ocenimo za vsako skupino/vsakega agenta posebej in glede na uvodne cilje posamezne skupine. Če so cilji doseženi po zaslugi sodelovanja, je ocena pozitivna.

Podrobneje si bomo ogledali dve izmed prej omenjenih težav - skromno oziroma neobstoječe sodelovanje javnosti in vandalizem. Predstavili bomo rešitve, ki so jih oblikovali v mestu Leipzig (Nemčija). Težavi sta povezani med seboj. Izvirata pa iz neobstoja družbene vloge zelene površine. Čim manj ljudi neko zeleno površino uporablja in se zanima zanjo, tem več vandalskih dejanj se zgodi na njej.

Pri nekaterih mestih partnerjih projekta GreenKeys je bilo pridobivanje podpore javnosti nova izkušnja. $\mathrm{V}$ nekaterih državah $\mathrm{v}$ preteklosti sodelovanje javnosti ni bilo običajno in pogosto. Čeprav tradicije sodelovanja ni bilo, so mesta partnerji priredila več javnih dogodkov, da so prebivalce obvestila o potekajočih delih.

Mesto Leipzig je vložilo veliko truda, da bi javnost spodbudilo k sodelovanju. Predvsem zato, ker se mesto na območju poskusnega projekta spoprijema s problematičnimi socialnimi razmerami. Tamkajšnja mladina ni imela na voljo razvedrilne strukture, zato so med mladimi izbruhnili spori (tolpe mladostnikov). Na začetku projekta je mesto poskušalo javnost pritegniti s krajevno delavnico, z oblikovalskim tekmovanjem in javnimi razpravami. Sledili so delavnice s prebivalci soseske in pogovori $\mathrm{z}$ mladimi ljudmi. Ta dejanja so pripomogla $\mathrm{k}$ temu, da so prebivalci projekt sprejeli; okrepilo pa se je tudi zanimanje političnih strank in celo župana. Dogodek je bil načrtovan in je vključeval tudi delavnico, v okviru katere so oblikovali mejni zid z grafiti. Najboljših 50 podob so predstavili v mestni hiši. Jeseni 2005 je potekala prva akcija - zid so poslikali $\mathrm{z}$ grafiti, in sicer $\mathrm{v}$ tesnem sodelovanju $\mathrm{Z}$

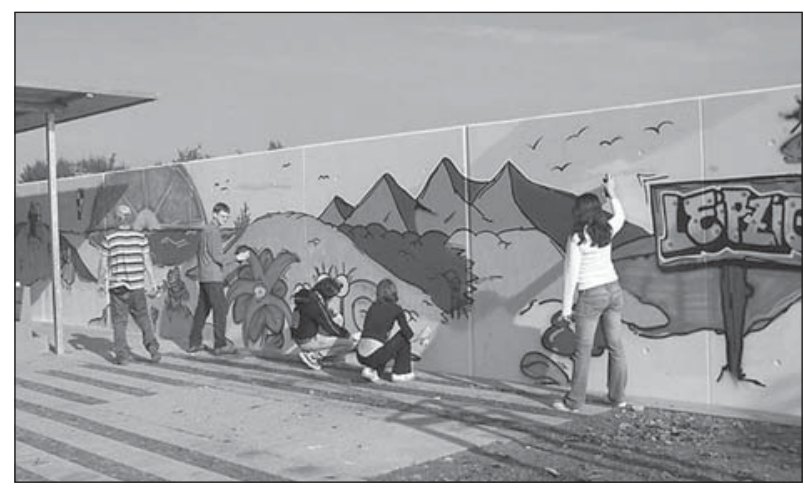

Slika 13: Mesto Leipzig je sodelovalo z mladostniki in jih vključilo v oblikovanje družabnega kotička za mladostnike v parku Bürgerpark. Tam so zid z grafiti poslikali mladostniki (vir: Mesto Leipzig, urad za parke in rekreacijo, 2005). 
bližnjo šolo, iniciativo krajanov in umetnikom za grafite. Obveščanje javnosti se je nadaljevalo. Z grafiti so uspešno poslikali še dva zidova. Javnost se je dejavneje vključila $v$ projekt. Nadaljevala sta se načrtovanje in graditev bližnjih zelenih površin. Predstavitve in krajevna posvetovanja so poskrbeli, da so se krajani in različne interesne skupine zavezali k dolgoročnemu vzdrževanju območja. K temu naj bi pripomogel zlasti javni podpis "pogodbe« $\mathrm{Z}$ mladimi o dolgoročnem vzdrževanju. Pričakujejo, da se bodo tudi tako izognili vandalizmu.

Pomemben vidik vključevanja javnosti je tudi natančna prepoznava in analiza interesnih skupin oziroma njihovih interesov. Vedeti je treba, kdo ima strokovno znanje in kdo se zanima za vprašanja, povezana z zelenimi površinami. Pri projektu GreenKeys je sodelovanje različnih interesnih skupin pri načrtovanju pripomoglo $\mathrm{k}$ temu, da so bili poskusni projekti zelo dobro sprejeti. V mestu Leipzig so se dogovorili celo o dolgoročnem vzdrževanju. Izkušnje kažejo, da je treba interesnim skupinam pokazati jasno skupno vizijo in kazalce učinkovitosti, če želimo zagotoviti uspeh.

\section{Priročnik projekta GreenKeys in obdobje po projektu}

Prepričani smo, da so vsi dosežki projekta GreenKeys - zlasti, prvič, izboljšave zelenih površin, ki jih je v 12 mestih omogočila izvedba poskusnih projektov; drugič, pobuda za oblikovanje strategije za mestne zelene površine in posvetovanje o njej, ter tretjič, izmenjava in posredovanje znanja in izkušenj - pripomogli k boljšemu zavedanju pomena zelenih površin in večjemu zanimanju zanje ter da bo mestna uprava lahko svoje zelene površine obravnavala bolj poglobljeno in intenzivneje.

V projektu GreenKeys so opisani metodologije in orodja predlagani kot pripomoček za prepoznavanje gonilnih sil in oblikovanje sistema za razvoj, za sprejemanje obsežnih strategij za mestne zelene površine in za spremljanje njihovega izvajanja. Projekt GreenKeys s to dokumentacijo podpira oblikovanje skupne vizije, ki bo mestom omogočila močno sonaravno samobitnost.

Rezultati projekta so zbrani v priročniku GreenKeys @ Your City - A Guide for Urban Green Quality. Priročnik je nastal v upanju, da bo navdihoval v duhu projekta GreenKeys. Izboljšanje zelenih po- vršin je zaveza za naložbo v prihodnost. Priročnik ponuja le predloge o tem, kako reševati težave, ne pa receptov in navodil, ki se jih je treba strogo držati. Namenjen je zlasti tistim, ki v praksi iščejo rešitve za posebne težave svojega mesta, in znanstvenikom ponuja namreč izhodišča za znanstvene razprave in zamisli za nujne nadaljnje raziskave.

Dr. Carlos Smaniotto Costa

Leibniz Institute of Ecological and Regional Development (IOER)

Dresden

E-pošta: c.smaniotto-costa@ioer.de

Dr. Juliane Mathey

Leibniz Institute of Ecological and Regional Development (IOER)

Dresden

E-pošta: j.mathey@ioer.de

Mag. Ina Šuklje Erjavec, univ. dipl. kraj. arh.

Urbanistični inštitut Republike Slovenije, Ljubljana

E-pošta: ina.suklje-erjavec@uirs.si

\section{Opomba}

[1] Seznam koristi in funkcij je dolg. Več podatkov najdete $v$ priročniku projekta GreenKeys, »GreenKeys @ Your City - A Guide for Urban Green Quality«. V nadaljevanju so naštete najpomembnejše koristi in dodatna literatura.

[2] Bolgarski mesti Kotel in Sofija ter zveza strokovnjakov za parke in krajino niso imeli nobene denarne podpore za sodelovanje pri projektu GreenKeys. Bolgarija ob pobudi za projekt in njegovem začetku še ni bila članica Evropske unije, zato ji ni bilo mogoče zagotoviti neposrednega financiranja iz skladov Evropske unije. Bolgarski partnerji so pozneje pripravili dodaten predlog za financiranje, ki pa je bil zavrnjen. Pomanjkanje denarne podpore je projektni ekipi povzročilo veliko težav, ki sta jih osebna zavzetost in zavzetost partnerjev rešili samo delno. Poskusnega projekta ni bilo mogoče uresničiti. Prav tako niso mogli oblikovati strategije zelenih površin. Bolgarski partnerji so v projektu GreenKeys sodelovali le pri delavnicah, v mreži in izmenjavi znanja. To je omogočila dodatna denarna podpora ministrstva za transport, gradbeništvo in urbanizem Zvezne republike Nemčije.

\section{Viri in literatura}

Barber, A. (2005) Green Future - A Study of the Management of Multifunctional Urban Green Spaces in England. Reading, Green Space Forum Ltd.

de Vries, S., idr. (2001) Benefits of Green Space for Physical Activity in Adults. Euro Leisure Congress. Nizozemska.

CABE Space (2004) Green Space Strategies - making the most of your parks and green spaces. London, Velika Britanija: Cabe Space. Dostopno na: http://www.cabespace.org.uk/data/pdfs/greenspacestrategies.pdf)

Greenkeys-Team (2006) Guideline for the General Procedure of Developing and Implementing an Urban Green Space Strategy. Dostopno na: http:// www.greenkeys-project.net/media/files.

GreenKeys-Team (2008) GreenKeys @ Your City - A Guide for Urban Green Quality. Dresden, IOER.

ODPM/Communities and Local Government 'Planning Policy Guidance Note 17: Open Space, Sport and Recreation'. London. Dostopno na: http://www.odpm.gov.uk

URGE-Team (2004) Making Greener Cities - A Practical Guide. UFZ-Bericht, 8(37) (Stadtökologische Forschungen). 